\title{
EXHAUSTION OF FEDERAL ADMINISTRATIVE REIVEDIES IN CASES UNDER SECTION 1981 OF THE CIVIL RIGHTS ACT
}

It is a general rule of administrative law that a party must exhaust available administrative remedies prior to seeking judicial rehef. 1 An exception to this general exhaustion doctrine has been developed by a line of Supreme Court cases which indicate that one need not exhaust his state administrative remedies prior to bringing suit under section 1983 of the Civil Rights Act of $1964 .^{2}$ In two recent cases $^{3}$ the Fifth Circuit has considered the question whether this exception should be extended to excuse exhaustion of federal administrative remedies in cases brought under section $1981^{4}$ of that Act. The ensu-

1. The Supreme Court has referred to this doctrine as "the long settled rule of judicial administration that no one is entitled to judicial relief for a supposed or threatened injury until the prescribed administrative remedy has been exhausted." Myers v. Bethlehem Shipbuilding Corp., 303 U.S. 41, $50-51$ (1938) (citation omitted).

The Supreme Court's mitial articulation of the doctrine in Prentis v. Atlantic Coast Line Co., 211 U.S. 210, 230 (1908) marked the beginning of widespread recognition of the doctrine. But manifestations of the doctrine were apparent in the early federal court decisions of Altschul v. Gettings, 86 F. 200 (C.C.D. Ore. 1898) and Dundee Mortgage Trust Inv. Co. v. Charlton, 32 F. 192 (C.C.D. Ore. 1887).

However, the exhaustion doctrine has not been consistently applied. Professor Davis has made the following observation: "The law embodied in the holdings clearly is that sometimes exhaustion is required and sometimes not." $3 \mathrm{~K}$. Davis $\S 20.01$. For general discussions of the exhaustion doctrine see $3 \mathrm{~K}$. DAVIS $\S \S 20.01-.10$ and L. JAFFE $424-58$.

2. 42 U.S.C. $\& 1983$ (1970). The statute reads:

Every person who, under color of any statute, ordinance, regulation, custom, or usage of any State or Territory subjects or causes to be subjected, any citizen of the United States or other person within the jurisdiction thereof to the deprivation of any rights, privileges or immunities secured by the Constitution and laws, shall be liable to the party injured in an action at law, suit in equity, or other proper proceeding for redress.

Section 1983 was enacted following the ratification of the fourteenth amendment in order to provide a federal remedy for discrimination which is the result of state action taken under color of state law. See United States v. Classic, 313 U.S. 299 (1941); Civil Rights Cases, 109 U.S. 3 (1883). For an excellent discussion of the cases relevant to the scope of section 1983, see Harrison v. Murphy, 205 F. Supp. 449, 45055 (D. Del. 1962).

Because of the emphasis on state action in section 1983 cases, they usually raise the question of exhaustion of state rather than federal administrative remedies. See, e.g., Damico v. California, 389 U.S. 416 (1967); McNeese v. Board of Educ., 373 U.S. 668 (1963).

3. Penn v. Schlesinger, 490 F.2d 700 (5th Cir. 1973); Beale v. Blount, 461 F.2d 1133 (5th Cir. 1972).

4. 42 U.S.C. $\$ 1981$ (1970). The statute reads:

All persons within the jurisdiction of the United States shall have the 
ing discussion will briefly review the exhaustion doctrine and the developinent of the section 1983 exception to that doctrine. Thereafter, it will critically examine the Fifth Circuit's rationale for refusing to extend to section 1981 cases the section 1983 exception and will suggest a inore basic analysis which would provide an alternative justification for that refusal.

Considerations of both procedural efficiency and comity underlie the exhaustion requireinent. ${ }^{5}$ Efficiency is proinoted by permitting administrative agencies to develop the facts of the cases with which they deal and to exercise discretion in their areas of expertise without the additional delay and expense which flow from interruption at the intermediate stages of the process. ${ }^{\circ}$ Moreover, a requireinent of ex-

same right in every State and Territory to make and enforce contracts, to sue, be parties, give evidence, and to the full and equal benefit of all laws and proceedings for the security of persons and property as is enjoyed by white citizens, and shall be subject to like punishment, pains, penalties, taxes, license, and exactions of every kind, and to no other.

Section 1981 was originally part of the Civil Rights Act of 1866, Act of April 9, 1866, ch. $31, \S 1$, 14 Stat. 27 , enacted subsequent to the ratification of the thirteenth annendment. Its stated purpose is the "protection of citizens of the United States in the enjoynent of certain rights, without discrimination on account of race, color, or previous condition of servitude . . . United States v. Cruikshank, 92 U.S. 542, 555 (1875). For a discussion of the statutory history of section 1981, see 1 B. Schwartz, StatuTORY HISTORY OF THE UNITED STATES: CIVIL RIGHTS 99-101 (1970).

Section 1981 is analogous to section 1983 in that it provides a cause of action for various discriminatory acts. However, in contrast to section 1983, section 1981 does not specifically imclude a "state action" requirement, see note 2 supra. But, until recently, it was widely accepted that section 1981, like section 1983, applied only to discrimination under color of state law. See, e.g., Valle v. Stengel, 176 F.2d 697 (3d Cir. 1949); Waters v. Paschen Contractors, Inc., 227 F. Supp. 659 (N.D. Ill. 1964). In Jones v. Alfred H. Mayer Co., 392 U.S. 409 (1968), however, the Supreme Court held that 42 U.S.C. $\$ 1982$ (1970) (a sister section to section 1981 which prohibits discrimination in transactions of property in nuch the same language as is used in section 1981) prohibited "all racial barriers in the acquisition of real and personal property." 392 U.S. at 439 (emphasis added). Subsequently, the Fifth Circuit extended the Jones rationale to suits under section 1981, lrolding that a riglit of action exists under section 1981 against a private employer. Sanders v. Dobbs Houses, Inc., 431 F.2d 1097 (5th Cir. 1970), cert. denied, 401 U.S. 948 (1971); accord, Waters v. Wisconsin Steel Works of Int'l Harvester Co., 427 F.2d 476 (7tl Cir.), cert. denied, 400 U.S. 911 (1970). In Penn v. Schlesinger, 490 F.2d 700 (5th Cir. 1973), this rationale was extended even further to reach discrimination by federal agencies as well as private employers and employers acting under color of state law. Id. at 702.

The section 1981 equal right "to make and enforce contracts" lias been interpreted as sufficiently broad to prohibit discrimination in most situations which involve employment contracts. See, e.g., Sanders v. Dobbs Houses, Inc., 431 F.2d 1097 (5th Cir. 1970) (racial job discrimination by private employer held actionable); Waters v. Wisconsin Steel Works of Int'l Harvester Co., 427 F.2d 476 (7th Cir. 1970) (racial discrimination by umion in its role as employees' agent leeld actionable).

5. See McKart v. United States, 395 U.S. 185, $193-95$ (1969); L. JAFFE 42426: Berger, Exhaustion of Administrative Remedies, 48 YALE L.J. 981, 983-85 (1939).

6. See McKart v. United States, 395 U.S. 185, 194 (1969); Berger, supra note 
haustion may also promote efficiency in that the particular issue in question may be rendered moot or insignificant by the final agency decision. ${ }^{7}$ The comity consideration flows from a recognition of the fact that administrative agencies, as entities separate from the judiciary, should be allowed to function with a minimum of judicial intcrference, especially when the matter involves an area in which the agency has special expertise or substantial discretionary authority. ${ }^{8}$ Commentators have differed over whether enforceinent of the exhaustion requireinent should be mandatory or within the court's discretion, ${ }^{0}$ but the Supreme Court recently stated that the application of the doctrine to specific cases should depend on the relation of the purposes of the requirement to the particular administrative scheme involved, thus apparently accepting the discretionary theory. ${ }^{10}$

Exhaustion is not required when the administrative procedure is inadequate to prevent irreparable imjury ${ }^{11}$ or when recourse to the administrative processes would be an exercise in futility. ${ }^{12}$ These in-

5, at 984. The importance of fact-finding by an expert administrative body has been specifically recognized by the Supreme Court in Interstate Commerce Commission cases. See, e.g., Board of R.R. Comm'rs v. Great N. Ry., 281 U.S. 412, 424 (1930); Great N. Ry. v. Merchants Elevator Co., 259 U.S. 285, 291 (1922).

7. See L. JAFFE 424; Berger, supra note 5, at 984. Professor Jaffe analogizes the reasons behind the exhaustion rule to the reasons supporting the general rule that review by a higher court is not available until the lower court has issued a final judgment. See, e.g., 28 U.S.C. §§ 1291-92 (1970).

8. See McKart v. United States, 395 U.S. 185, 194-95 (1969); Prentis v. Atlantic Coast Line Co., 211 U.S. 210, 229-32 (1908); L. JAFFE 425; Berger, supra note 5, at $984-85$.

9. Compare $3 \mathrm{~K}$. Davis $\S 20.03$ and $\mathrm{L}$. JAFFE $432-37$ (discretionary) with Berger, supra note 5, at 1006 (niandatory).

10. McKart v. United States, 395 U.S. 185, 193 (1969).

11. See, Deering Milliken, Inc. v. Johnston, 295 F.2d 856 (4th Cir. 1961). In Deering Milliken, the petitioner was being irreparably injured by the delay caused by the National Labor Relations Board in its hearing process. Id. at 866 . The court noted that "the Board does not here contend that there is any adninistrative remedy available to the plaintiff for the protectiou of the right asserted," id., and concluded:

[T] The District Court had jurisdiction of this controversy and ... the plain-

tiff was not precluded from turning to that court for the protection of its

right, since there was no available administrative remedy to make applicable

the principle requiring prior exhaustion of such remedies. Id.

12. Perhaps the clearest example of futility occurred in Williams v. Richardson, 347 F. Supp. 544 (W.D.N.C. 1972), in which the agency head was required by statute to reject the plaintiff's claim. The court did not require the "empty formality" of an administrative ruling denying the claim, $i d$. at 548 , but futility need not be so patently obvious before exhaustion will be excused. See, e.g., Houghton v. Shafer, 392 U.S. 639, 640 (1968) (per curiam); McNeese v. Board of Educ., 373 U.S. 668, 674-76 (1963); Eisen v. Eastman, 421 F.2d 560, 568-69 (2d Cir. 1969), cert. denied, 400 U.S. 841 (1970); Potter v. McQueeney, 338 F. Supp. 1133 (D.R.I. 1972); cf. 3 K. Davis § 20.07 . 
stances are actually in harmony with the exhaustion doctrine because the logic of the rule presupposes the existence of a viable administrative remedy which offers protection of the asserted right sufficiently substantial to warrant prohibiting immediate recourse to the courts. ${ }^{13}$

There are, however, several important true exceptions to the exhaustion doctrine. ${ }^{14}$ Exhaustion may be avoided when an agency makes an especially egregious error, such as assertion of a power contrary to a specific statutory provision. ${ }^{15}$ Under a closely related exception, the Second Circuit has dispensed with exhaustion when a petitioner has made a substantial assertion that his constitutional rights have been violated by agency action. ${ }^{16}$ If an agency action raises a

13. If recourse to the prescribed administrative process would cause irreparable harm, there is clearly no administrative remedy vis-a-vis that particular injury; thus exhaustion never enters the picture. L. JAFFE 426; see note 11 supra. Similarly, the considerations of comity and efficiency which underlie the exhaustion doctrime, see notes 5-8 supra and accompanying text, are not advanced by requiring recourse to agency procedures when such recourse is almost certain to be futile. See note 12 supra.

14. See 3 K. DAVIS $\$ \S 20.02-.03$; L. JAFFe 432-37; Note, Interim Relief and Exhaustion of Administrative Remedies: A Study in Judicial Confusion, 1973 DuKE L.J. 275, 278-81, in 1972 Developments.

15. See Leedom v. Kyne, 358 U.S. 184 (1958). The National Labor Relations Act provides that to determine the appropriate unit for collective bargaining purposes "the Board shall not (1) decide that any unit is appropriate for such purposes if such unit includes both professional employees and employees who are not professional employees unless a majority of such professional employees vote for inclusion in such unit . . ." 29 U.S.C. $\$ 159$ (b)(1) (1970). In Leedom, the Board refused to take a vote to determine whether a majority of the professional employees affected by the action before the Board would vote for mclusion in such a unit, and imcluded both professionals and non-professionals $m$ the bargaining unit. Suit was brought in district court by the professional einployees seeking to have the Board's action set aside. 358 U.S. at 18586. The Supreme Court dispensed with exhaustion and held that the district court had jurisdiction since the Board's order was, on its face, an attempt to exercise power contrary to a specific provision of the National Labor Relations Act.

However, Leedom "represents ouly a narrow and rarely successfully invoked exception" which is applicable only when the agency decision is "infused with error which is of a summa or magna quality as contraposed to decisions which are simply cum error." United States v. Feaster, 410 F.2d 1354, 1368 (5th Cir.), cert. denied, 396 U.S. 962 (1969).

16. See Fay v. Douds, 172 F.2d 720 (2d Cir. 1949). In Fay, a labor union, without first exhausting its administrative remedies under the National Labor Relations Act, sued in district court alleging that its status as the exclusive bargaining agent had been terminated without a hearing by the National Labor Relations Board. The union argued that it had been deprived of property (its status as exclusive bargaining agent) without due process of law. Id. at 723. Since the asserted constitutional right was not "transparently frivolous," the court held that the district court had jurisdiction to decide the issue. Id.; accord, Fitzgerald v. Hampton, 467 F.2d 755 (D.C. Cir. 1972); Amos Treat \& Co. v. SEC, 306 F.2d 260 (D.C. Cir. 1962).

However, this exception has been narrowly construed. See McCulloch v. LibbyOwens-Ford Glass Co., 403 F.2d 916, 917 (D.C. Cir. 1968), cert. denied, 393 U.S. 1016 (1969); Boire v. Miami Herald Publishing Co., 343 F.2d 17, 21 n.7 (5th Cir. 1965). 
question which significantly affects the national interest, exhaustion may not be required.17 Finally, the exhaustion requirement is not applied rigorously when its application would deprive a criminal defendant of his defense. ${ }^{18}$

The inost recently developed exception to the exhaustion rule consists of dispensing with the exhaustion of state administrative remedies in section 1983 civil rights cases. As previously noted, ${ }^{10}$ section 1983 provides a judicial remedy to a person whose constitutional or statutory rights have been violated under color of state law. In Monroe v. Pape, ${ }^{20}$ plaintiffs brought suit in federal district court against Chicago police officers who allegedly violated section 1983 by breaking into the plaintiffs' apartment and conducting two warrantless searches which resulted in damage to their property. ${ }^{21}$ The officers argued in the Supreme Court, ${ }^{22}$ inter alia, that, since state law provided a judicial remedy ${ }^{23}$ for the asserted injury, the suit had been improperly brought. $^{24}$ Reviewing at length the statutory history of section $1983,{ }^{25}$

17. See McCulloch v. Socieđad Nacional de Marineros de Honduras, 372 U.S. 10, 17 (1963).

18. See McKart v. United States, 395 U.S. 185 (1969). See also Layton \& Fine, The Draft and Exhaustion of Administrative Remedies, 56 GEo. L.J. 315, 322-23 (1967). McKart was a criminal case in which the defendant was charged with failure to report for military induction. His defense was that his exemption had been wrongly denied. The government sought to block the use of that defense because of the defendant's failure to contest the denial of his exeniption through the proper administrative procedures. In allowing the defendant to raise his defense, the Court noted that "use of the exhaustion doctrine in criminal cases can be exceedingly harsh." 395 U.S. at 197.

Application of the exhaustion doctrine in cases hike McKart would serve to deprive one of his criminal defense because of his failure to assert a right in an earlier adininistrative proceeding. Thus, such cases are clearly different from the ordimary exhaustion case in which the doctrine inerely serves to delay the judicial assertion of a right.

19. See note 2 supra.

20. 365 U.S. 167 (1961).

21. Id. at 169 .

22. The court of appeals relied on Stift v. Lynch, 267 F.2d 237 (7th Cir. 1959) (holding that state law enforcement officers are immune from prosecution under section 1983), in affirming the dismissal of the plaintiffs' claim by the district court. Monroe v. Pape, 272 F.2d 365, 366 (1959). The police officers urged adoption of the Stift holding in the Suprenie Court, but the Court held that action by state law enforcement officers is actionable since it is taken under color of state law. 365 U.S. at 183-87. Monroe is noost widely known for this holding on the meaning of "under color of state law."

23. The constitution of Illinois prohibits umreasonable searches in much the same language as the fourth amendinent, ILL. CoNST. art. $1, \S 6$, and provides that a person shall have a reniedy for all injuries to his privacy, $i d$. art. $1, \S 12$.

24. 365 U.S. at 173-83.

25. The present section 1983 was originally passed as part of the Ku Klux Klan Act of 1871, Act of April 20, 1871, ch. 22, $\S 1,17$ Stat. 13. The impetus for the 
the Court found that section's principal aims to be (1) to "override certain kinds of state laws," law was inadequate," 27 and, more broadly, (3) "to provide a federal remedy where the state remedy, though adequate in theory, was not available in practice."28 Reasoning that Congress enacted section 1983 to provide a federal alternative to state procedures for vindicating individual rights, the Court held that exhaustion of state judicial relief was not required in any case brought under section 1983: "The federal remedy is supplementary to the state remedy, and the latter need not be first sought and refused before the federal one is invoked."29

In McNeese v. Board of Education, ${ }^{30}$ black public school students, alleging that their school was segregated in violation of the fourteenth amendment, sued the board of education in federal district court under section 1983.31 The school board urged dismissal on the ground that the students should have been required to pursue the state administrative grievance procedure $^{32}$ before filing suit. ${ }^{33}$ Although

passage of that Act was provided by part of President Grant's message to Congress:

A condition of affairs now exists in some States of the Union rendering life and property insecure and the carrying of the mails and the collection of revenues dangerous. The proof that such a condition exists in some localities is now before the Senate. That the power to correct these evils is beyond the control of State anthorities I do not donbt; that the power of the Execntive of the United States, acting within the limits of existing laws, is snfficient for present emergencies is not clear. CoNG. GLOBE, $42 \mathrm{~d}$ Cong., 1st Sess. 244 (1871).

The historical climate which spawned the Act is also demonstrated by the congressional debates. For example, Representative Lowe of Kansas graphically illustrated one view of prevailing conditions:

While murder is stalking abroad in disguise, while whippings and lynchings and banishments have been visited upon unoffending American citizens, the local administrations have been found inadequate or unwilling to apply the proper corrective. Combinations, darker than the night that hides them, conspiracies, wicked as the worst of felons could devise, liave gone unwhipped of justice. Id. at 374 .

See also S. REP. No. 1, 42d Cong., 1st Sess. (1871); 1 B. SchwARTZ, supra note 4, at 591-653.

26. 365 U.S. at 173.

27. Id.

28. Id. at 174 .

29. Id. at 183. The Court rejected the argument that since the political climate which existed in the states in 1871 , see note 25 supra, no longer exists, the purposes of section 1983 do not suffice to permit direct access to a federal judicial remedy:

Although the legislation was enacted because of the conditions that existed in the South at that time, it is cast in general language and is as applicable to Illinois as it is to the States whose names were mentioned over aud again in the debates. It is no answer that the State has a law which if enforced would give rehef. Id.

30. 373 U.S. 668 (1963).

31. Id. at $669-70$.

32. This administrative procedure involved a hearing by the Snperintendent of Public Instruction on any complaint alleging segregation made by 50 , or 10 percent, of 
McNeese involved exhaustion of a state administrative rather than state judicial remedy, ${ }^{34}$ the Supreme Court relied heavily upon the discussion in Monroe v. Pape of the purposes behind section $1983^{35}$ and held that the suit had been properly brought. Significantly, however, the Court aliso questioned the adequacy of the state administrative remedy; ${ }^{36}$ thus, it is unclear whether the decision was based on the broad principle that exhaustion of state administrative remedies is unnecessary in all section 1983 cases or on the narrower ground that the administrative remedy was in fact inadequate. ${ }^{37}$

However, in Damico v. California, ${ }^{38}$ a per curian opinion, ${ }^{30}$ the

the residents of a school district, whichever is less. If the hearing determines that the complaint is substantially correct, the Superintendent must request the Attorney General to apply to the courts for appropriate relief. ILL. ANN. STaT. ch. 122, \$2219 (1962).

33. Both the district court, McNeese v. Board of Educ., 199 F. Supp. 403 (E.D. III. 1961), and the court of appeals, McNeese v. Board of Educ., 305 F.2d 783 (7th Cir. 1962), accepted this argument and dismissed the suit for failure to exhaust the administrative remedy.

34. The Supreme Court has been criticized for its "precipitous application of a decision concerning exhaustion of alternate judicial remedies [Monroe] to the quite different problem of exhaustion of state administrative remedies [McNeese]." Note, Exhaustion of State Remedies Under the Civil Rights Act, 68 CoLUM. L. Rav. 1201, 1204 (1968). Since the first important administrative agency in the United States (the Interstate Commerce Commission) was not established until 1887, see L. JAFFE 9, the availability of state administrative relief for particular grievauces was clearly not contemplated when section 1983 was originally enacted in 1871, see note 2 supra. Thus, the Court could have easily limited Monroe to state judicial remedies. However, the Court's extension of Monroe to excuse exhaustion of state administrative, as well as judicial, remedies seems reasonable in light of Monroe's finding that section 1983 was meant to provide a federal judicial alternative, without regard to what state relief might be available. See note 29 supra.

35. See 373 U.S. at 671-74.

36. Id. at 674-76. See notes 11-13 supra aud accompanying text. On the other hand, the administrative remedy was not deemed inadequate by the district court, McNeese v. Board of Educ., 199 F. Supp. 403, 407-08 (E.D. III. 1961), the court of appeals, McNeese v. Board of Educ., 305 F.2d 783, 786 (7th Cir. 1962), or by Mr. Justice Harlan in dissent, McNeese v. Board of Educ., 373 U.S. 668, 677-78 (1963).

37. A majority of the courts interpreted McNeese broadly as dispensing with the requirement of state exhaustion in section 1983 cases. See, e.g., Springfield School Comm. v. Barksdale, 348 F.2d 261, 265 (1st Cir. 1965) (dictum); Powell v. Workmen's Compensation Bd., 327 F.2d 131, 135 (2d Cir. 1964); York v. Story, 324 F.2d 450, 456 (9th Cir. 1963); Lee v. Hodges, 321 F.2d 480, 484 (4th Cir. 1963) (dictum); Ferrell v. Dallas Ind. School Dist., 261 F. Supp. 545, 549 (N.D. Tex. 1966); Scolnick v. Winston, 219 F. Supp. 836, 839 (S.D.N.Y. 1963), cert. denied, 379 U.S. 825 (1964). However, some courts limited McNeese as applying only when the state remedy was inadequate. See, e.g., Kabelka v. City of New York, 272 F. Supp. 998, 999-1000 (S.D. N.Y. 1967) (dictuin); Christmas v. Board of Educ., 231 F. Supp. 331,339 (D. Md. 1964) (dictum).

38. 389 U.S. 416 (1967) (per curiam).

39. In his dissent, Justice Harlan protested the deciding of the issues without briefs and oral argument. Id. at 420 (dissenting opinion). 
Supreme Court treated as settled the question of exhaustion of state administrative remedies in section 1983 suits. Damico involved a challenge in federal court to the constitutionality of a provision of the California Welfare and Institutions Code which regulates the operation of the California Aid to Families with Dependent Children (AFDC) program. ${ }^{40}$ No complaint had previously been filed with the state agency that had responsibility for hearing complaints alleging wrongful deprivation of AFDC benefits. ${ }^{41}$ A three-judge court dismissed the suit for failure to exhaust the state administrative relief, but the Supreme Court reversed, interpreting $M c N e e s e$ as standing for the proposition that "relief under the Civil Rights Act may not be defeated because rehef was not first sought under the state law which provided [an administrative] remedy." ${ }_{22}$ Thus, Damico clearly suggests that exhaustion is not required of a plaintiff suing under section 1983, notwithstanding the availability of adequate state administrative remedies. ${ }^{43}$

40. The provision under attack denied aid to persons whose need for benefits was due to parental separation or desertion of less than three months' duration, unless a suit for divorce had been filed. Cal. Welfare and Institutions Code $\$ \S 11250$, 11254 (West 1972); 30 OP. ATT'Y GeN. 135 (Cal. 1957).

41. In order to qualify for federal funds under the federal AFDC program, Title IV of the Social Securities Act, 42 U.S.C. $\$ \S 601-44$ (1970), a state must have an approved plan. Id. $\S 601$. The agency in question in Damico had been established pursuant to a requirement that an approved plan have such an agency to hear grievances. Id. $\$ 602(\mathrm{a})(4)$.

42. 389 U.S. at 417 (brackets in original).

43. The Fifth Circuit has consistently read Damico as excusing exhanstion of state administrative remedies in all section 1983 cases. See Beale v. Blount, 461 F.2d 1133, 1139 n.11 (5th Cir. 1972); Chisley v. Richland Parish School Bd., 448 F.2d 1251, 1252-53 (5th Cir. 1971); Hobbs v. Thonupson, 448 F.2d 456, 461 (5th Cir. 1971); Burnett v. Short, 441 F.2d 405, 406 (5th Cir. 1971) (dicta); Moreno v. Henckel, 431 F.2d 1299, 1305-07 (5th Cir. 1970).

The Fifth Circuit is not alone in its broad reading of Damico. See Stradley v. Andersen, 456 F.2d 1063, 1064 (8th Cir. 1972); Johnson v. San Francisco Unified School Dist., 339 F. Supp. 1315, 1342 (N.D. Cal.), application for stay pending appeal denied, 404 U.S. 1215 (1971); Callahan v. Sanders, 339 F. Supp. 814, 817 (M.D. Ala. 1971); C. WRIGHT, LAW OF FEDERAL COURTS 187 n.6 (2d ed. 1970).

However, the Suprenue Court's language in King v. Smith, 392 U.S. 309 (1968), a case decided subsequent to Damico, has been interpreted by some courts as limiting Damico. In King, the plaintiffs challenged the constitutionality of a regulation pronulgated by the Alabama AFDC program, which denied AFDC benefits to children whose mother cohabited with, or was frequently visited by, an able bodied male regardless of whether that male actually contributed to, or was legally obligated to contribute to, the support of the children. Exhaustion of the state administrative renedy was not required, but the Supreme Court seemingly linited Damico by stating that it established the proposition that exhaustion of administrative remedies is not required in section 1983 cases "where the constitutional challenge is sufficiently substantial . . . to require the convening of a three-judge court." Id. at 312 n.4.

In Metcalf v. Swank, 444 F.2d 1353 (7th Cir. 1971), vacated and remanded, 406 U.S. 914 (1972), a majority of the Seventh Circuit interpreted Damico and King 
Since the above Supreme Court decisions dealt only with the ap-

as excusing exhaustion only when a three-judge court is convened to decide whether a statute is unconstitutional on its face. Id. at 1356; accord, UAW v. State Farm Mut. Auto. Ins. Co., 350 F. Supp. 522, 527 (N.D. IIl. 1972); Marm v. University of P.R., 346 F. Supp. 470, 477 (D.P.R. 1972). The Suprente Court later vacated the decision in Metcalf, Metcalf v. Swank, 406 U.S. 914 (1972), and renianded for consideration in light of Carter v. Stantou, 405 U.S. 669 (1972), a case "indistinguishable" from Damico in which exhaustion was excused. Id. at 671. The case of Houghton v. Shafer, 392 U.S. 639 (1968) (per curiam), also renders the Metcalf analysis doubtful. In Houghton, a state prisoner who alleged unlawful confiscation of legal materials by prison authorities was not required to exhaust his remedies in the prison administration even though a three-judge court had not been convened. Id. at 640. These facts seem to indicate that the Metcalf court attributed too much significance to King's footnoted reference to three-judge courts and "substantial" constitutional challenges. See Brooks v. Center Township, 485 F.2d 383, 386 (7th Cir. 1973).

In Eisen v. Eastman, 421 F.2d 560 (2d Cir. 1969), cert. denied, 400 U.S. 841 (1970), the Second Circuit interpreted the Damico line of decisions as standing for the proposition that "[e]xhaustion of state administrative remedies is not required where the administrative remedy is inadequate . . . or where it is certainly or probably futile . ..." Id. at 569; accord, Marin v. University of P.R., 346 F. Supp. 470, 476-77 (D.P.R. 1972); Vistamar, Inc v. Vasquez, 337 F. Supp. 375, 378 (D.P.R. 1971); cf. Kochie v. Norton, 343 F. Supp. 956, 958-60 (D. Conn. 1972). The Eisen court concluded:

We shall need much clearer directions than the Court has yet given or, we

believe, will give, before we hold that plaintiffs in such cases may turn their

backs on state administrative reınedies and rush into a federal forum ....

421 F.2d at 569 .

One difficulty with the Eisen court's reading of the cases is that, although the Supreine Court in Houghton v. Shafer, 392 U.S. 639 (1968) (per curiam), indicated that pursuit of the state administrative relief, the exhaustion of which was excused, might well have been futile, the Houghton Court went on to state that "[i]n any event, resort to these remedies is unnecessary in hight of our decisions in Monroe, . . McNeese, and Damico ...." 392 U.S. at 640 (einphasis added); see Metcalf v. Swank, 406 U.S. 914 (1972) (dissenting opinion). A second difficulty is the fact that the Supreine Court chose to base its opinions in McNeese and Damico on the purposes of section 1983, see notes 30-42 supra and accoinpanying text, since the futility of seeking, or the inadequacy of, the adıninistrative remedy would seem sufficient to excuse exhaustion even in suits not brought under section 1983 . See notes 11-13 supra and accompanying text.

The First Circuit still requires exhaustion in section 1983 cases brought by school teacliers whose contracts are not renewed. See Beattie v. Roberts, 436 F.2d 747, 74849 (1st Cir. 1971); Dunhain v. Crosby, 435 F.2d 1177, 1180-81 n.2 (1st Cir. 1970); Drown v. Portsinouth School Dist., 435 F.2d 1182, 1186 n.10 (1st Cir. 1970), cert. denied, 402 U.S. 972 (1971). The First Circuit has explained:

We require exhaustion, in part, because we hesitate to hold nuembers of school colnmittees hable for tentative dismissal decisions when they are denied the opportunity to viow the issue in the light of the facts and arguments which the affected teachers might introduce in a formal hearing. Beattie v. Roberts, 436 F.2d 747, 748-49 (1st Cir. 1971).

However, in view of the recent Supreme Court opinion in Preiser v. Rodriguez, 411 U.S. 475 (1973), the Fifth Circuit's broad interpretation of Damico seems correct. In Preiser, state prisoners brought section 1983 actions, in conjunction with a habeas corpus action, alleging that their good-behavior-time credits had been unconstitutionally cancelled. The six-man majority held that the habeas corpus action is the sole federal 
plication of the exhaustion doctrine in cases brouglit under section 1983 of the Civil Rights Act, the question remains whether the exception apparently established by those decisions should be extended to excuse exhaustion of federal administrative remedies by plaintiffs asserting civil riglts violations. Recently, in two cases involving alleged employment discrimination by federal agencies, the Fifth Circuit has considered the argument that, since exhaustion of state administrative remedies is not required in actions brought under section 1983 of the Civil Rights Act, ${ }^{44}$ exhaustion of federal administrative remedies should be excused in actions brought under section 1981 of that Act. ${ }^{45}$ In Beale v. Blount, ${ }^{46}$ the plaintiff, alleging that he had been discharged from his position as a letter carrier solely on the basis of race, brought suit against the government under section $1981 .^{47}$ Prior to bringing

remedy for a state prisoner challenging the fact or duration of his confinement, id. at 489; thus, complete exhaustion of the state administrative remedy was required by statute, see 28 U.S.C. $\$ 2254$ (b) (1970). However, the opinion noted that "if a remedy under the Civil Rights Act is available, a plaimtiff need not first seek redress in a state forum." 411 U.S. at 477 ; see id. at 494 . In view of the majority's recognition that the policies behind exhaustion are quite strong im cases brought by state prisoners, id. at 491-93, the opinion's broad language is especially significant. In addition, the three dissenters clearly interpreted the section 1983 exception very broadly. Id. at 500-01, 522.

44. See note 2 supra.

45. See note 4 supra. A somewhat similar question has arisen in pre-1972 cases where a plaintiff alleging unlawful employment practices has sued under section 1981 without first utilizing the procedures of Title VII of the Civil Rights Act, 42 U.S.C. $\$ \S 2000 \mathrm{e}-1$ to -15 (1970). Title VII proscribed certain discriminatory employment practices, id. $\S \S 2000 \mathrm{e}-2$ to -3 , and established the Equal Employment Opportunity Cominission (EEOC), id. $\S 2000 \mathrm{e}-4$. The EEOC was empowered to imvestigate charges of unlawful employment practices and to attempt to eliminate such practices through conciliation, $i d$. $\$ 2000 \mathrm{e}-5$, but its enforcement powers were virtually non-existent. See BNA, The EQUAL EMPLOYMENT OPPORTUNITY ACT OF 1972, 58-59 (1973). The courts split on the question of whether the EEOC procedure could be deliberately bypassed. Compare Caldwell v. National Brewing Co., 443 F.2d 1044, 1046 (5th Cir.), cert. denied, 405 U.S. 916 (1971), and Young v. International Tel. \& Tel. Co., 438 F.2d 757, 761-63 (3d Cir. 1971) (both liolding one may deliberately bypass the EEOC procedure) with Waters v. Wisconsin Steel Workers of Int'1 Harvester Co., 427 F.2d 476, 487 (7th Cir.), cert. denied, 400 U.S. 911 (1970) (a reasonable excuse must be pleaded for bypassing the EEOC procedure). The situation in the EEOC cases differed from that in Beale v. Blount, 461 F.2d 1133 (5th Cir. 1972), and Penn v. Schlesinger, 490 F.2d 700 (5th Cir. 1973), two recent Fifth Circuit cases, in that the administrative procedures available in Beale and Penn, see notes 49, 58 infra, were far more likely to resolve the complaint than were the conciliatory EEOC procedures. However, the 1972 amendments to Title VII, 42 U.S.C.A. $\$ \S 2000 \mathrm{e}-1$ to -16 (1974), have strengthened the enforcement procedures of the EEOC, see BNA, supra at 58-59, so that the situations are now more analogous.

46. 461 F.2d 1133 (5th Cir. 1972).

47. Such a claim is coguizable under section 1981. See Keys v. Continental III. Nat'l Bank \& Trust Co., 357 F. Supp. 376, 379 (N.D. Ill. 1973). See note 4 supra. 
suit Beale had contested his discharge through administrative review procedures which had upheld the decision to terminate his employment. ${ }^{48}$ However, he had not raised the charge of racial discrimination in these administrative proceedings. ${ }^{49}$ Nevertheless, the plaintiff contended that the Monroe-McNeese-Damico line of cases established the proposition that a plaintiff under the Civil Rights Act need not exhaust available administrative remedies prior to seeking judicial relief. ${ }^{50}$ The court rejected this argument, concluding that those three cases were based upon the rationale that there is "no rational basis for requiring a claimant to exhaust state administrative remedies before being permitted to institute an action in federal court to redress the deprivation of a federal right." ${ }^{\text {"1 }}$ The Beale court noted that the plaintiff's situation, as one contesting federal agency action under section 1981, was "totally dissimilar" from that of a plaintiff attacking state action under section $1983^{52}$ since the federal government is "on record" by act of congress and executive order as being officially opposed to racial discrimination in einployment practices. ${ }^{53}$ Consequently, the court dismissed the suit for failure to comply with "the time-tested requirement that available administrative remedies be exhausted" before judicial relief is sought. ${ }^{54}$

In a 1973 decision, Penn v. Schlesinger, ${ }^{55}$ the Fifth Circuit again

The court held that Beale's claims for injunctive relief and damages were barred by sovereign immunity, but it declared that the part of the action that was in the nature of a writ of mandamus was not so barred. $461 \mathrm{~F} .2 \mathrm{~d}$ at 1137-38.

48. Beale's employment was terminated because of alleged threats made in arguments with his supervisor. $461 \mathrm{~F} .2 \mathrm{~d}$ at $1135-36$. In the administrative process challenging his termination, Beale limited his defense to matters in extenuation. Id. at 1136 .

49. At the time of Beale's termination in 1970, the available administrative grievance procedure was set ont in the Civil Service Commission's Regulations, 5 C.F.R. $\S \S 713.201-.241(1970)$. The regulations provided for mandatory attempts at informal resolution, $i d$. $\$ \S 713.213,713.217$ (a), an investigation by the agency's Director of Equal Employment Opportunity, id. $\$ 713.216$, an opportunity to have findings made at a full evidentiary hearing considered in the decision by the agency head, id. $\$ \S 713$.217(b), 713.218,713.221(a), and a review of an agency head's adverse decision by the Board of Appeals and Review, id. §§ 713.231-.236.

In 1972, these regulations were supplemented by adding to the Equal Employment Opportunities Act provisions designed to make the Civil Service Commission more forceful and effective. 42 U.S.C.A. $\$ 2000 \mathrm{e}-16$ (1974).

50. 461 F.2d at 1138.

51. Id. at 1139 (emphasis added).

52. Id.

53. $I d$.

54. $1 d$.

55. 490 F.2d 700 (5th Cir. 1973). Discrimination in the promotion process is actionable under section 1981. See Copeland v. Mead Corp., 51 F.R.D. 266 (N.D. Ga. 1970). See note 4 supra. 
addressed the exhaustion issue in the context of a 1981 suit brought by aggrieved federal employees. In Penn, two black civilian employees of the Department of Defense alleged that they had been denied promotions solely on the basis of their race. ${ }^{56}$ On numerous occasions both plaintiffs had complained to their white supervisors about their lack of advancement. However, neither had been informed of his right to submit his complaint to an Equal Employment Opportunity officer $^{57}$ and thereby initiate the administrative processes specifically established to resolve racial discrimination grievances. ${ }^{58}$ Judge Tuttle, writing the opinion of the court, initially observed that the Beale decision clearly established that 1981 plaintiffs may not deliberately ignore federal administrative remedies prior to seeking judicial relief. ${ }^{59}$ However, he distinguished Penn from the Beale decision by noting that in the latter case the plaintiff had "deliberately bypassed" his administrative remedies. ${ }^{60}$ In contrast, the Penn plaintiffs had not been informed of their right to an administrative remedy. ${ }^{61}$ Thus, Judge Tuttle held that "exhaustion is coinpleted at the point where agency personnel [refuse] to further process grievances and pass thein on to the next link in the chain of command."62 Judge Morgan concurred with the result, but stongly argued that exhaustion of administrative remedies is not required in any action brought under the Civil Rights Act, relying on the Damico opinion. ${ }^{63}$ Although Judge Morgan conceded that Damico and its predecessors only involved failure to exhaust state, as opposed to federal, administrative remedies, he contended that the policies which require exhaustion of state administra-

56. $490 \mathrm{~F} .2 \mathrm{~d}$ at 701 .

57. In fact, one supervisor, who was an Equal Employment Opportunity Counselor (and thus under a duty to inform an aggrieved person of his rights, 5 C.F.R. $\$$ 713.217(b) (1971) ), told one plaintiff that "he would have to file a suit if he expected to carry his complaint further." 490 F.2d at 705 .

58. The administrative procedures available were set forth in 5 C.F.R. $\S \S 713.201-$ .241 (1971) and were the same as those available in 1970 to Beale. See note 49 supra.

59. Judge Tuttle observed that Beale had drawn "a distinction between federal court actions against federal officials and federal court action agamst a state agency or official. This distinction, having been drawn, is binding on us." $490 \mathrm{F.2d}$ at 705 n.11.

60. Id. at 706 .

61. See note 57 supra.

62. 490 F.2d at 706 .

63. Curiously, Judge Morgan asserted that "Judge Tuttle correctly states that in light of our conclusion that the plaintiffs exhausted all available administrative remedies, it is unnecessary to decide whether exhaustion was required." Id. at 707. This interpretation of Judge Tuttle's opinion appears untenable in view of the fact that Judge Tuttle cited, as controlling authority, the Beale holding that exhaustion of federal administrative remedies is required. See note 59 supra. 
tive remedies are even more compelling than those which require exhaustion of federal administrative remedies, since the federal-state comity considerations are stronger in the former instance. ${ }^{04}$ Therefore, he concluded that "if state exhaustion is not required, a fortiori, exhaustion of federal remedies should not be required."

In dissent, Judge Godbold joined the majority in maintaining that the exhaustion requirenent fully applied in 1981 cases but strongly disagreed with Judge Tuttle's view that the Penn plaintiffs had sufficiently exhausted available administrative reinedies. The dissent did not directly address the broad contention of the concurrence that exhaustion is not required in civil rights cases. Rather, Judge Godbold merely outlined the principles whicl underlie the exhaustion doctrine and then, focusing narrowly on the facts of the case before him, applied those principles to conclude that sucl1 "policies are disserved by permitting these plaintiffs to skip all the administrative procedural steps that begin with the filing of a written complaint."B6 In sum, Judge Tuttle, by finding the court bound by the liolding in Beale, and Judge Godbold, by examining the facts of the Penn case only in light of the general primciples underlying the exhaustion doctrine, apparently agreed that the exhaustion doctrine applies in suits against the federal government under section 1981 but disagreed as to what constitutes compliance with that requirement. Judge Morgan, in contrast, would not require exhaustion of available administrative remedies, either state or federal, in any civil rights case.

The separate rationales relied upon by Judge Tuttle and by dissenting Judge Godbold in reaching the same conclusion as to the applicability of the exhaustion requirement in actions brought against the federal government under section 1981 are equally unpersuasive. As noted above, Judge Tuttle, albeit somewhat reluctantly, found the court bound by the broad lolding in Beale that, since the federal government is "on record" as being officially opposed to racial discrimination in employment, the exception to the exhaustion requirement which has been granted to plaintiffs in actions contesting state discriminatory practices under section 1983 is inapplicable to plaintiffs proceeding against the federal government under section $1981 .^{67}$ While

64. Id. at 707.

65. Id.

66. Id. at 712. Judge Godbold argued that allowing the Penn plaintiffs to bypass the comprehensive administrative review procedures prevented the administrative agency involved from (1) developing a factual record, (2) exercising its discretion and expertise, and (3) correcting its own errors. Id.

67. See note 59 supra and accompanying text. 
it will be seen that adherence to this distinction by the Beale court was sound, ${ }^{68}$ the reasoning by which it was reached is not persuasive since, in addition to the federal government, many states are on record as opposed to discrimination in employment. ${ }^{69}$ Equally unconvincing is the dissent's argument that exhaustion was required in the circumstances of the Penn case merely because the purposes of the doctrine would be served thereby. The conclusion that this line of reasoning is far from dispositive becomes immediately apparent when it is realized that those same purposes may also be contravened by the still valid holding of the Monroe-McNeese-Damico line of cases that a section 1983 plaintiff need not exhaust his state administrative remedies.

Although the opinions are unconvincing, the result reached by the Beale court and the Penn dissent ${ }^{70}$ may be justified by an alternative analysis. When one focuses on the reasoning which led the $\mathrm{Su}-$ preme Court in the Monroe-McNeese-Damico line of cases to develop what the Fifth Circuit has interpreted as an absolute exception to the exhaustion of state administrative remedies in section 1983 cases, it becomes apparent that the rationale which underlies that exception will not support the extension of that exception to excuse exhaustion of federal administrative remedies in section 1981 cases. Section 1983 was enacted at a time when there was a felt need for a federal remedy for civil rights violations because the political climate in some states cast doubt on the efficacy of state remedies. ${ }^{71}$ Therefore, the Supreme Court concluded that Congress enacted section 1983 in order to provide a federal judicial remedy as an alternative to both state judicial and state administrative remedies in civil rights cases. ${ }^{72}$ Thus, the alternative nature of the section 1983 remedy provided the basis for dispensing with exhaustion of state administrative remedies in section 1983 cases. $^{73}$ However, in section 1981 cases dealing with

68. See notes 70-75 infra and accompanying text.

69. See, e.g., Alas. Stat. ch. 80, $\$ 18.80 .010-.300$ (1969); Cax. Labor Code $\S \S$ 1410-33 (West 1972); HawaII Rev. STat. ch. 378, $§ \S 378-1$ to -10 (1973 Supp.); Ill. ANN. Stat. ch. 48, §§ 851-61 (1973 Supp.); N.Y. ExEc. LaW \$§ 290-301 (McKinney 1973 Supp.); OноO REv. CODE, ch. 4112, §§ 4112.01-.99 (1973). About three-fourths of the states have laws prohibiting enployment discrimination which are enforced by soine type of agency. BNA, supra note 45 , at 73-80.

70. The concurring judge in Penn concentrated solely on the consideration of federal-state comity to conclude that exhaustion should be excluded in section 1981 cases as well as section 1983 cases. See notes 63-65 supra and accompanying text. That analysis seems faulty in that it fails to recognize that the factors which led to the section 1983 exception are not present in section 1981 cases. See notes 71-75 infra and accoinpanying text.

71. See note 25 supra.

72. See notes 30-43 supra and accompanying text.

73. See text accoinpanying note 29 supra (quotation from Monroe opinion). 
allegations of employment discrimination by the federal government, a federal remedy already exists, ${ }^{74}$ although that remedy is administrative. And clearly, section 1981 was not enacted in order to provide a federal judicial remedy as an alternative to federal administrative remedies. ${ }^{75}$ Therefore, simce the "alternative remedy" analysis which underlies the section 1983 state exhaustion exception is mapplicable to the situation of exhaustion of federal administrative remedies in section 1981 cases, the Fifth Circuit was justified in refusing to dispense with the requirement of exhaustion of federal administrative remedies in section 1981 cases.

74. See note 49 supra.

75. The first important federal administrative agency, the Interstate Commerce Commission, was not established until 1887, see L. JAFFE 9, twenty-one years after the original enactment of section 1981 in 1866 . See note 4 supra. 